\title{
Antilarval and antimicrobial activity of waterborne metabolites of the sponge Callyspongia (Euplacella) pulvinata: evidence of allelopathy
}

\author{
Sergey Dobretsov, Hans-Uwe Dahms, Pei-Yuan Qian* \\ Department of Biology and Coastal Marine Laboratory, Hong Kong University of Science and Technology, Clear Water Bay, \\ Kowloon, Hong Kong SAR
}

\begin{abstract}
Antilarval, antidiatom and antibacterial activity of sponge metabolites has been well documented in previous laboratory experiments. In this investigation we attempted to link the results of our earlier laboratory experiments of antifouling activity of the sponge Callyspongia (Euplacella) pulvinata (Porifera: Demospongiae, Haliclonidae) to those measured in the field. Our laboratory experiments showed that conditioned seawater (CSW) of the sponge strongly inhibited the growth of the benthic diatom Nitzschia paleaceae and the settlement of the tubeworm Hydroides elegans, but had no effect on the growth of 9 bacterial strains isolated from natural biofilms. When diluted 5 times, the CSW still exhibited antilarval and antidiatom activities. In field experiments, sponge specimens were placed within 13 and $50 \mathrm{~cm}$ of Petri dishes that were serving as attachment substrates for microand macrofouling organisms. Synthetic sponge-like material was used to mimic sponges for the controls. The results showed that after $7 \mathrm{~d}$, diatom attachment on dishes placed in close vicinity to the sponge was inhibited. Bacterial densities on the experimental dishes did not differ significantly $(p>0.05)$ from those in the control dishes. Microfouling communities, which developed on both experimental and control dishes in the field, had similar effects on the settlement of $H$. elegans under laboratory conditions. After $28 \mathrm{~d}$, an early community had been established, consisting of 5 species of green algae, 2 species of brown algae, 2 species of red algae and 5 species of invertebrates. We found strong negative effects of the presence of sponges and the position of the plate on the total percentage of cover, Shannon-Wiener diversity, as well as on the species richness of macrofouling communities. In the experimental dishes, the percentage of coverage of both macroalgae (Ulva sp., Ectocarpus sp., Enteromorpha sp., unidentified brown algae) and invertebrates (Obelia sp., H. elegans) decreased. ANOSIM (analysis of similarity) and a SIMPER (similarity percentage) analysis demonstrated that the composition of macrofoulers on the dishes were positively affected both by the presence of a sponge and with decreasing distance from it. Our results suggest that waterborne compounds of C. pulvinata inhibit settlement of micro- and macrofoulers not only on its own surface but also on non-living surfaces nearby.
\end{abstract}

KEY WORDS: Sponge $\cdot$ Antifouling defence $\cdot$ Assays $\cdot$ Recruitment $\cdot$ Larvae $\cdot$ Bacteria $\cdot$ Diatoms Biofouling communities $\cdot$ Waterborne metabolites $\cdot$ Epibiosis

\section{INTRODUCTION}

Living or non-living surfaces in the marine environment are continuously exposed to and colonised by microorganisms and metacellular dispersal stages. In the case of soft-bodied marine organisms, the sustainable extent of microbial colonisation and macroorgan- ismic settlement (micro- and macrofouling) is influenced by mechanical and chemical effects of mucoid exudates and bioactive metabolites produced either by the host (basibiont) itself or by host-symbiotic organisms (Wahl 1997). Microbial epibiosis can be harmful (e.g. microbial pathogens) or beneficial (e.g. microbial origin of chemical defence mechanisms against 
pathogens or predators) for the host organism (basibiont) (Wahl 1997, Newbold et al. 1999).

Marine biofilms developed in a natural environment can enhance (Kirchman et al. 1982, Harder et al. 2002, Lau et al. 2002) or inhibit (Maki et al. 1988, Holmström et al. 1992, Lau \& Qian 1997, Lau et al. 2003) larval settlement. The basibiont can control larval recruitment directly (by excretion of antifouling compounds) and indirectly (by the control of the microorganismic composition of the biofilm via suppressing inductive bacterial strains but enhancing the growth of non-inductive ones). It has been demonstrated that the marine bacterium Pseudoalteromonas tunicata, isolated from the surface of the tunicate Ciona intestinalis, produced a range of antibacterial, antidiatom and antilarval compounds (Holmström et al. 1992, James et al. 1996). We obtained comparable results in earlier laboratory experiments with surface-associated bacteria from the alga Ulva reticulata (Dobretsov \& Qian 2002) and the sponge Mycale adhaerens (Lee \& Qian 2003).

A diverse array of metabolites has been isolated from marine sponges (e.g. Sera et al. 1999, Blunt et al. 2003). Whether secondary metabolites, however, are produced by the sponges themselves or by symbiotic bacteria (Bergquist 1978), alga (Kobayashi \& Kitagawa 1998), or fungi (Hoeller et al. 2000) has rarely been studied. One reason for the high chemical diversity of sponge-derived metabolites could be that these metabolites are actually produced by a wide spectrum of associated microorganisms (cf. Armstrong et al. 2001) that are known to be present in most marine sponge species studied so far (Unson et al. 1994, Thoms et al. 2003). Several investigations have shown that microbiota from sponges differ from those associated with non-living substrata in ambient proximity (Burja \& Hill 2001, Hentschel et al. 2002, Lee \& Qian 2003), suggesting that these associations are specific. Various aspects of symbiotic associations differ according to the sponge species studied: the abundance of microorganisms, their location in the sponge tissue, their phenotypic and genetic diversity, and the specific way of interaction with their host (Becerro et al. 1994, Friedrich et al. 2001). Most of this biota comprises primarily heterotrophic bacteria (Hentschel et al. 2001) and cyanobacteria (Thacker \& Starnes 2003). Associations with dinoflagellates (Burja \& Hill 2001), unicellular algae (Ruetzler 1985), fungi (Hoeller et al. 2000) and actinomycetes are also known (Burja \& Hill 2001, Margot et al. 2002).

Many sponge- or sponge-symbiont-derived metabolites provide potent antibacterial, antifungal, antifeeding, or/and antifouling compounds (Becerro et al. 1997, Davis 1998, Austin 2001). It has been demonstrated that conditioned seawater and extracts from freshly collected sponges show a high degree of antibacterial activity (Newbold et al. 1999). In most cases, antibacterial natural compounds are waterborne toxins showing selective activity against specific bacterial strains (Thakur \& Anil 2000, Kelman et al. 2001, Harder et al. 2002). It has been demonstrated that polar as well as non-polar extracts of sponges contain terpenoids (Tomono et al. 1998, Sera et al. 1999), ceratinamine and ceratinamides that inhibit larval settlement of the barnacle Balanus amphitrite and the mollusc Mytilus edulis (Tsukamoto et al. 1997).

However, most of the evidence that sponge-derived compounds have antimicrobial and antilarval activity comes from laboratory experiments. Only a few field studies have shown that marine organisms can control fouling not only on their own surface but also on nearby substrates (Dobretsov 1999, Dobretsov \& Wahl 2001, Wahl 2001). Field experiments have demonstrated that the larvae of the blue mussel Mytilus edulis selectively settled on artificial substrates in close vicinity $(<1 \mathrm{~m})$ to the green algae Cladophora rupestris and avoided substrates near the brown algae Laminaria saccharina (Dobretsov \& Wahl 2001). Similar results were obtained in experiments on the settlement of other invertebrate larvae (Wahl 2001), algal spores and protozoans (Wahl \& Mark 1999). The only other field experiment studying the chemical effects on nearby communities by 6 different species of sponges (Chondrilla sp., Halichondria sp., Haliclona sp., Tedania sp., Lissodendoryx sp. and Terpios sp.) was performed by Bingham \& Young (1991), who demonstrated that sponges did not inhibit the recruitment of 25 invertebrate species.

The sponge Callyspongia (Euplacella) pulvinata is commonly found in the South China Sea and is rarely fouled in the natural environment. Our preliminary observations indicated that this sponge might produce waterborne compounds to control micro- and/or macrofouling not only on the sponge surface but also on nearby substrates. In the present study, the waterborne compounds of C. pulvinata were used for an indepth analysis of potential chemical defence mechanisms against micro- and macrofouling. A combined array of in vitro antibacterial, antidiatom and antilarval assays, together with a complex in situ investigation, was employed (for the first time) to estimate the antifouling potential of a sponge species. The objectives of the current study therefore were: (1) to examine the effects of waterborne metabolites of the sponges on the growth of 9 strains of marine bacteria, on the benthic diatom Nitzschia paleacea, as well as on the settlement of Hydroides elegans larvae under laboratory conditions; (2) to investigate the possible effect of the microbial communities formed in situ near the sponge on the larval settlement of $H$. elegans in vitro; (3) to investigate the effects of living sponges on the formation of micro- and macrofouling communities in the field. 


\section{MATERIALS AND METHODS}

Laboratory experiments. Collection of sponges and preparation of conditioned seawater: Specimens of the sponge Callyspongia (E.) pulvinata were collected from the tethering ropes of fish cages belonging to the rafts of a fish farm at Wong Shek Pier, Hong Kong $\left(22^{\circ} 25^{\prime} \mathrm{N}, 114^{\circ} 20^{\prime} \mathrm{E}\right)$. The sponges were carefully brought to the surface, transferred to large buckets, and either taken to the laboratory or used on a nearby raft for field experiments. They were blotted dry and weighed at the fish farm and their tissue volume was determined by water displacement. A reference sample was stored in $96 \%$ ethanol for subsequent taxonomic identification. A specimen of C. pulvinata $(530 \mathrm{~g}$ wet wt) was broken off the substratum and immediately transported to the laboratory, where it was exposed to 2.21 of autoclaved filtered $(0.22 \mu \mathrm{m})$ seawater (AFSW) for $1 \mathrm{~h}$. The conditioned seawater (CSW) thus obtained was filtered through $0.22 \mu \mathrm{m}$ mesh and deep-frozen $\left(-20^{\circ} \mathrm{C}\right)$ for the use in bioassays. The sponge was not cut or otherwise affected. A faint sponge-specific smell was usually discernible after the conditioning process, but the sponge did not show the effects of stress and could be maintained further under through-flow conditions in the laboratory for $10 \mathrm{~d}$. A series of $0.5 \times$ and $0.1 \times$ dilutions of the CSW were made for the various experiments.

Larval settlement bioassay: Adults of the tubeworm Hydroides elegans were collected from submerged rafts of the same fish farm at Wong Shek, Hong Kong. Larval cultures were prepared and maintained according to Bryan et al. (1997). Only competent larvae were included in the bioassays. Competency of $H$. elegans larvae was determined by their characteristic morphology and by a bioassay with the phosphodiesterase inhibitor 3-isobutyl-1-methylxanthine (IBMX, Fluka) at $10^{-4} \mathrm{M}$ solution in AFSW (Pechenik \& Qian 1998). Two trials were run. In the first, the effect of Petri dishes exposed to biofouling in the close vicinity of the sponge (for details see following subsection 'Field experiment') was tested on larval settlement. We placed 20 larvae into each of the experimental dishes. Experiments were conducted for $24 \mathrm{~h}$ at $24^{\circ} \mathrm{C}$, and then swimming and settled larvae were counted under the microscope. The second experiment investigated the effect of sponge CSW on the settlement of competent larvae of $H$. elegans. A larval bioassay was conducted with replications $(n=6)$ in multiwell polystyrene dishes (\#3047, Falcon, USA) containing 15 larvae of $H$. elegans in each well. AFSW-filled dishes were used as controls. IBMX was used as an artificial stimulator for larval attachment at $10^{-4} \mathrm{M}$ in AFSW (Lau \& Qian 1997, Pechenik \& Qian 1998). Larval attachment assays were run at $24^{\circ} \mathrm{C}$ under continuous illumination for $24 \mathrm{~h}$.
After this period of time, swimming, settled and dead larvae were counted under a dissecting microscope.

Antibacterial assays: To investigate the antibacterial effect of CSW, $3 \mu$ of CSW at its original concentration was added to sterilised $6 \mathrm{~mm}$ diameter circular discs of filter paper (Whatman No. 1, disc volume $=20 \mathrm{~mm}^{3}$ ) (Acar 1980). An additional set of discs with $10 \mathrm{mg} \mathrm{ml}^{-1}$ of streptomycin was added and used as the positive controls. A disc with AFSW was used as a negative control. First, bacteria (Vibrio sp. UST950701-007; V. halioticoli UST010723-002; V. alginolyticus UST981130062; V. proteolyticus UST991130-028; V. furnissii UST 010723-010; V. harveyi UST020129-010; V. hollisae UST991130-052; Pseudoalteromonas sp. UST010723006, Staphylococcus haemolyticus UST950701-004) originating from natural biofilms from Hong Kong waters were inoculated onto the agar. All bacteria were obtained from the culture collection of the Hong Kong University of Science and Technology. Second, dried discs with sponge CSW, negative and positive controls were placed on the surface of the agar plates. The agar plates were incubated for $24 \mathrm{~h}$ at $30^{\circ} \mathrm{C}$ until bacteria developed in a confluent film. The zones of growth inhibition between the disc and the bacterial lawn (inhibition radius) was measured to the nearest $0.5 \mathrm{~mm}$. The experiment was run in 5 replicates.

Antidiatom bioassay: Antidiatom activity of epibiotic bacteria was tested according to a protocol developed by Dobretsov \& Qian (2002). In this test, $1 \mathrm{ml}$ of CSW from sponges at concentrations of $1 \times, 0.5 \times$ and $0.1 \times$ were added to Petri dishes containing $3 \mathrm{ml}$ of algal culture of the diatom Nitzschia paleacea (about $2 \times 10^{3} \mathrm{cells} \mathrm{ml}^{-1}$ ). After an incubation period of $2 \mathrm{~d}$ at $25 \pm 1^{\circ} \mathrm{C}$, under a L:D cycle of $15: 9 \mathrm{~h}$, the numbers of dead and living diatoms were counted under the microscope (Axiophot, Zeiss; magnification 1000×). For the control, $1 \mathrm{ml}$ of AFSW was used. The experiment was run with 5 replicates.

Field experiment. The investigation was conducted at the same fish farm at Wong Shek Pier, Hong Kong. In order to analyse the antifouling effect of the sponge Callyspongia (E.) pulvinata under natural conditions, we used specially designed frames (Fig. 1); 5 experimental and 4 control frames were deployed in our experiments. All frames were placed on a floating pontoon more than $5 \mathrm{~m}$ away from each other. Each rectangular frame (size $0.62 \times 0.75 \mathrm{~m})$ was constructed from PVC pipes $(21 \mathrm{~mm}$ in diameter). The frame was subdivided into 3 sections. In the central part of the frame, a mesh bag (mesh diameter $10 \mathrm{~mm}$ ) containing a living sponge (580 to $650 \mathrm{~g}$ wet wt) was tethered in the centre of each frame. On each raft, 6 experimental dishes (Falcon, $50 \mathrm{~mm}$ in diameter) were placed vertically in Positions 1 and 2 (i.e. at a distance of 0.13 and $0.5 \mathrm{~m}$ from the centre of the sponge, respectively: Fig. 1). On control rafts, synthetic bath sponges of comparative size were used. 


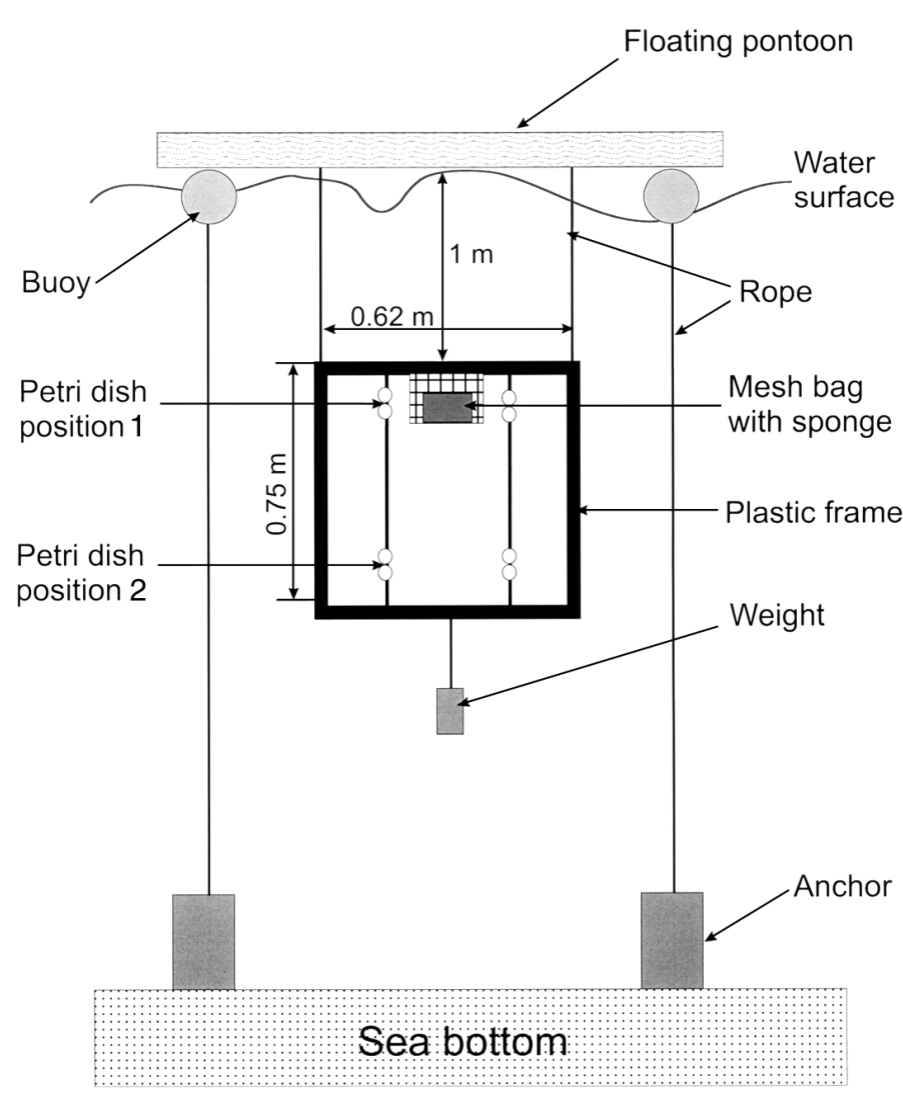

Fig. 1. Experimental frame used in field experiment for analysis of antifouling effects of the sponge Callyspongia (E.) pulvinata under natural conditions at fish farm near Wong Shek Pier, Hong Kong. Tide fluctuation during experiments was 0.6 to $2.4 \mathrm{~m}$

After 7 d, 4 dishes were retrieved from each raft for bacterial and diatom counts: 2 dishes from Positions 1 and 2 of each frame were formalin-fixed and used for counts of bacterial and diatom densities (for details see following subsection). The dominant diatoms on the dishes were identified to genera using a key to the marine benthic diatoms of China (Jin et al. 1985). The other 2 dishes were immediately transferred to the laboratory and used for the larval settlement bioassay (see preceding subsection). After 4 wk from the onset of the experiments, species composition and abundances of macrofouling algae and invertebrate species on the Petri dishes were analysed under a dissecting microscope. Percentage cover was estimated on the basis of 3 random fields (diameter $1.8 \mathrm{~cm}^{2}$ ). As a measure of species diversity, the Shannon $H^{\prime}$ and Simpson $1-\lambda, \lambda$, $\lambda^{\prime}, 1-\lambda^{\prime}$ diversity indices, as well as Hill numbers $N_{1}$, $\mathrm{N}_{2}, \mathrm{~N}_{\infty}, \mathrm{N}_{10}, \mathrm{~N}_{10}{ }^{\prime}, \mathrm{N}_{21}, \mathrm{~N}_{21}$ ' and rarefaction (Warwick \& Clarke 1995, Clarke \& Gorley 2001) were calculated using PRIMER 3.1 software (Plymouth Marine Laboratory). Margalef's species-richness index (Warwick \& Clarke 1995) was also calculated.
Bacterial and diatom counts. Bacterial and diatom abundances in the dishes were determined after $7 \mathrm{~d}$ in the field experiments. The attached bacteria were visualised with the DNA-binding fluorochrome 4,6diamidino-2-phenylindole (DAPI, Fluka) at $0.5 \mathrm{mg} \mathrm{ml}^{-1}$. Formalin-fixed $(4 \%$ in AFSW) dishes $(n=2)$ were rinsed with AFSW and stained with DAPI for $15 \mathrm{~min}$. The number of bacteria in 5 randomly selected fields was then estimated under an epifluorescence microscope (Axiophot, Zeiss; magnification 1000 $\times_{i} \lambda_{\text {ex }}=$ $359 \mathrm{~nm}, \lambda_{\text {em }}=441 \mathrm{~nm}$ ).

Statistical analysis. The numbers of attached larvae in the laboratory experiments were transformed into percentages and the percentages were arcsine-transformed. In the case of zero metamorphosed larvae, a value of $1 / 4 \mathrm{n}$ ( $\mathrm{n}=$ number of larvae in a single replicate) was given to improve the arcsine transformation (Zar 1996). The normality assumption was verified with the Shapiro-Wilk's test (Shapiro \& Wilk 1965). Differences between experimental and control larvae were determined by 1-way ANOVA followed by a least-signifinant difference (LSD) post-hoc test (Zar 1996). The density of bacteria and diatoms was squareroot-transformed in order to ensure normality of variance and analysed with 1-way ANOVA followed by an LSD post-hoc test. We used a 2-way ANOVA to test the effects of sponge and depth on total coverage and diversity of macrofoulers. Prior to analysis, percentage cover data were arcsine-transformed to achieve homogeneity of variances. Post-hoc multiple comparisons were perfomed using the LSD test. In all cases, the threshold for significance was $5 \%$. The data presented in the relevant figures here are not transformed. The effects of the presence or absence of a sponge colony on community structure were analysed using ANOSIM (analysis of similarity) and SIMPER (similarity percentage) procedures (PRIMER 3.1 software, Plymouth Marine Laboratory), based on multi-dimensional scaling (MDS) of the Bray-Curtis similarity index (Clarke \& Gorley 2001). Species diversity was compared with that of controls by multiple pairwise comparison (Dunnett's $t$-test) (Zar 1996).

\section{RESULTS}

\section{Laboratory experiments}

Larval settlement bioassay. In the presence of CSW from the sponge, the settlement of Hydroides elegans larvae was significantly different from that of the control (Fig. 2A, ANOVA: $F=77.7, \mathrm{p}<0.0000001$ ). Highest settlement was in the dishes with FSW (control) and $10 \times$-diluted $(0.1 \times) \mathrm{CSW}$, the second highest settlement was found on the dishes with $5 \times$-diluted CSW. 
Lowest settlement was in the dishes with undiluted CSW.

The survival rate of Hydroides elegans larvae in the dishes with sponge CSW varied during the experiment (Fig. 2B, ANOVA: $F=9.4, \mathrm{p}<0.0000001$ ). There was no significant toxic effect (LSD test; $\mathrm{p}>0.05$ ) of diluted CSW at $0.5 \times$ and $0.1 \times$ or of FSW on larvae. Undiluted CSW caused $80 \%$ larval mortality.

Bacterial disc-diffusion bioassay. Antibacterial activity of CSW from the sponge Callyspongia (E.) pulvinata was tested against bacterial isolates from the biofilm using a standard paper-disc method. CSW from the sponge and negative control (AFSW) did not suppress
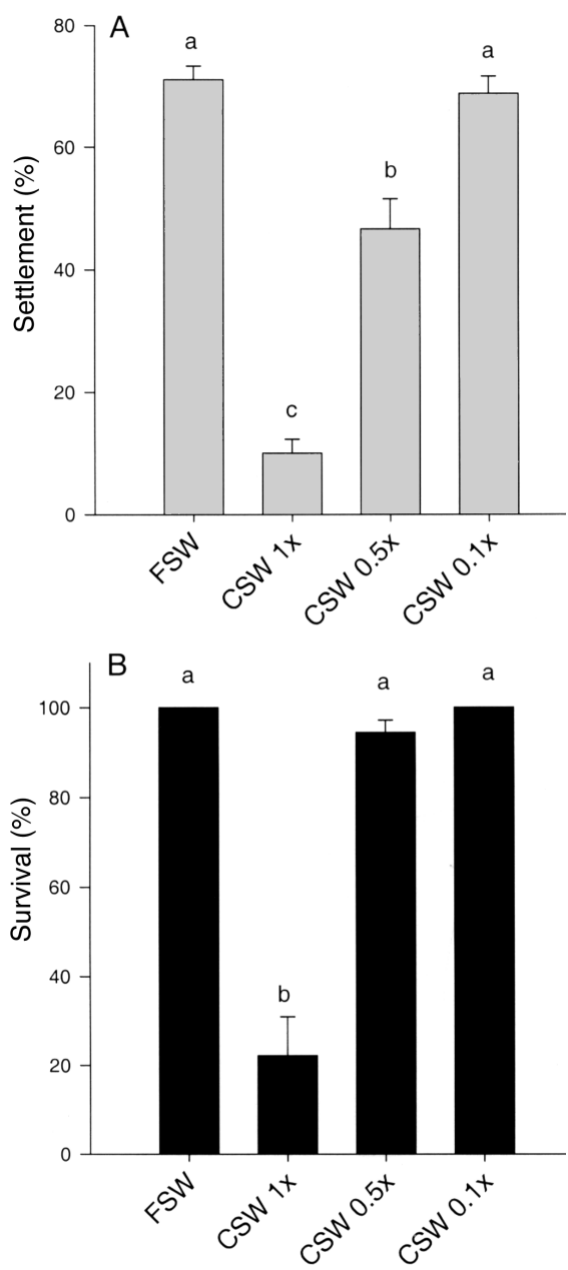

Fig. 2. Hydroides elegans. (A) Larval settlement and (B) survival at 3 concentrations $(1 \times, 0.5 \times, 0.1 \times)$ of sponge conditioned seawater (CSW) after $24 \mathrm{~h}$ incubation. Phosphodiesterase inhibitor 3-isobutyl-1-methylxanthine was used as an artificial stimulator for larval attachment at $10^{-4} \mathrm{M}$ in filtered seawater (FSW). FSW was used as a control. Experiments were conducted under continuous illumination at $24^{\circ} \mathrm{C}$. Data are means $\pm \mathrm{SE}$ of 6 replicates. Data that are significantly different according to LSD test (ANOVA: $p<0.05$ ) are indicated by different letters above bars the growth of isolates. All bacterial isolates were sensitive to the positive control (streptomycin).

Diatom growth bioassay. There were significant differences in the densities of the benthic diatom Nitzschia paleacea in the presence of sponge CSW (Fig. 3, ANOVA: $F=78.9, \mathrm{p}<0.000001$ ). CSW diluted $10 \times$ and FSW (control) had no effect on the densities of diatoms (LSD-test, $\mathrm{p}>0.05$ ). CSW diluted $5 \times$ resulted in a moderate density of diatoms. Undiluted CSW achieved the lowest density of diatoms. As a whole, CSW significantly inhibited the growth of the pennate diatom $N$. paleacea (LSD-test, $\mathrm{p}<0.05$ ).

\section{Field experiment}

Effect of waterborne sponge compounds on microfouling. After $7 \mathrm{~d}$, the bacterial community in the Petri dishes was dominated by rod-shaped and coccoid bacteria. Their densities varied from $3.9 \times 10^{4}$ cells $\mathrm{mm}^{-2}$ to $1.5 \times 10^{4}$ cells $\mathrm{mm}^{-2}$. The following diatom genera were dominant: Achnantes, Nitzschia, Navicula, Licmophora, Synedra, Amphora, Diploneis. The densities of diatoms fluctuated between 0.6 and $6.6 \times 10^{4}$ cells $\mathrm{mm}^{-2}$ among dishes.

Bacterial densities in the control Petri dishes (containing the sponge mimics) and experimental (with living sponges) frames were the same (Fig. 4A, LSD-test, $\mathrm{p}>0.05)$, while bacterial densities in the Petri dishes at Positions 1 and 2 were significantly different (LSD test, $\mathrm{p}<0.05$ ). The number of bacteria decreased (Fig. 4A) with increasing distance from the sponge as well

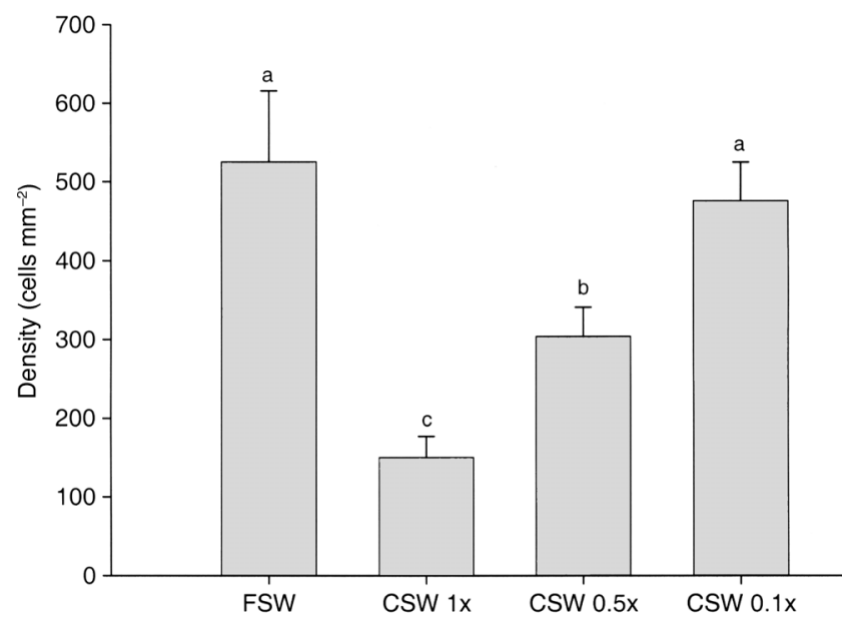

Fig. 3. Nitzschia paleacea. Growth of diatoms at 3 concentrations $(1 \times, 0.5 \times, 0.1 \times)$ of sponge conditioned seawater (CSW). Filtered seawater (FSW) was used as a control. Data are means $\pm \mathrm{SE}$ of 5 replicates. Experiments were run for $48 \mathrm{~h}$ at $25 \pm 1{ }^{\circ} \mathrm{C}$ in an L:D cycle of $15: 9 \mathrm{~h}$. Data presentation as in Fig. 2 ( $n=5$ replicates) 

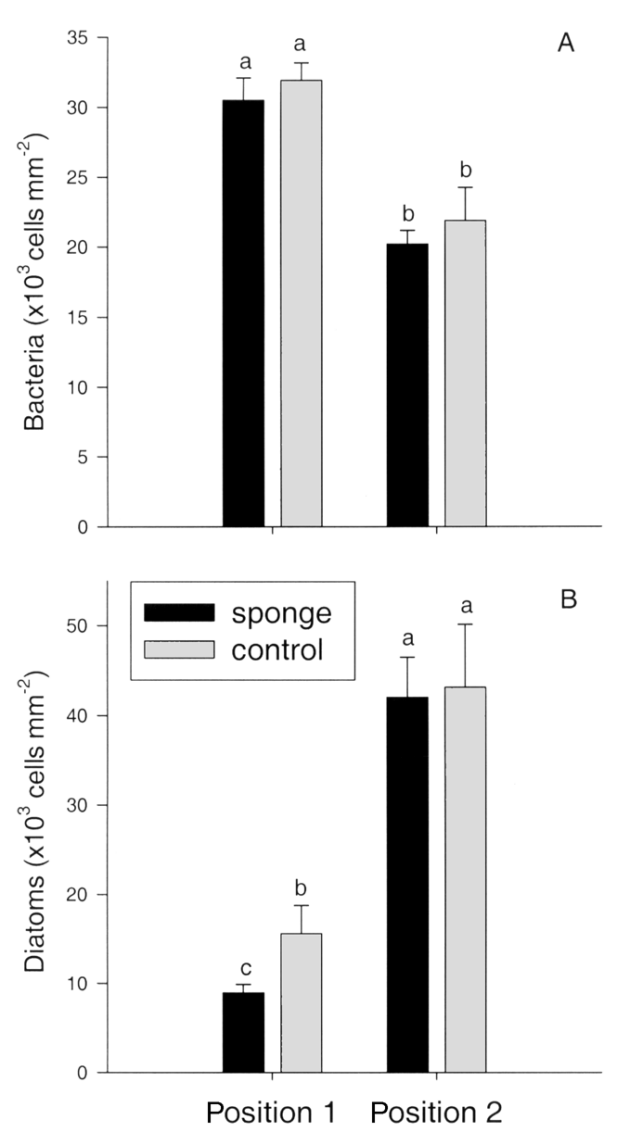

Fig.4. Densities of (A) bacteria and (B) diatoms in treatment and control Petri dishes at Positions 1 and 2 of frames $7 \mathrm{~d}$ after start of the experiment near the fish farm at Wong Shek Pier. Data presentation as in Fig. 2 ( $\mathrm{n}=5$ replicates)

as with increasing depth between Positions 1 and 2 (Fig. 1).

At Position 1, which was closer to the living sponge, diatom densities were significantly lower (LSD test, $\mathrm{p}<0.05$ ) than on control frames (Fig. 4B). There were no significant differences (LSD test, $\mathrm{p}>0.05$ ) in diatom density between the experimental and the control rafts at Position 2. This may have been due to the dominance of the small (10 to $15 \mu \mathrm{m})$ diatom species Diploneis sp. on the dishes at Position 1.

In general, field experiments demonstrated that sponges inhibited diatom attachment on Petri dishes near the sponge, but did not effectively suppress the growth of bacteria. Bacterial density decreased with increasing depth and distance from the sponge, while the density of diatoms increased on dishes exposed at Position 2.

Effect of microbial communities on larval settlement. Because the densities of bacteria and diatoms on the dishes exposed to fouling on the left and right sides of the frames were not significantly different (ANOVA: $F=0.8, \mathrm{p}>0.05)$, they were combined. There were no

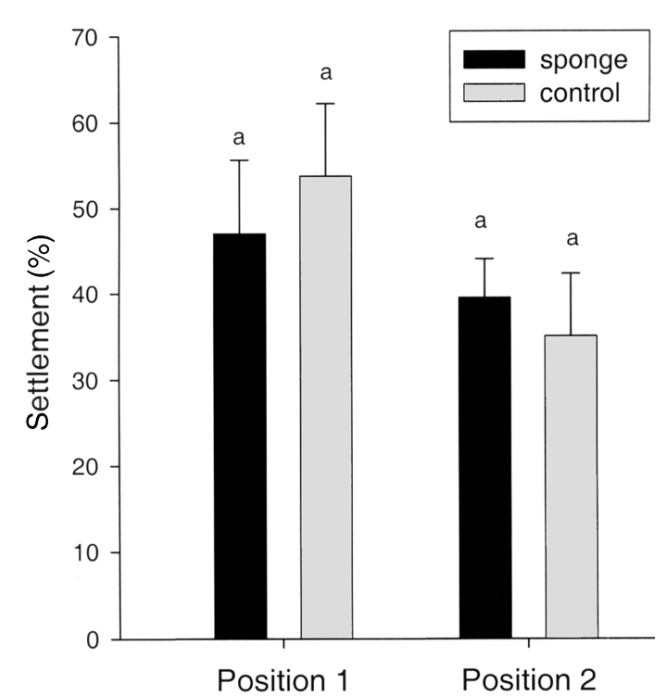

Fig. 5. Hydroides elegans. Effect on settlement of larvae of microfouling communities developed on the treatment and control Petri dishes in frames exposed in the field for $7 \mathrm{~d}$. Experiments were conducted in laboratory under continuous illumination at $24^{\circ} \mathrm{C}$ for $24 \mathrm{~h}$. Data presentation as in Fig. 2 ( $\mathrm{n}=5$ replicates)

differences in the settlement of Hydroides elegans larvae on the Petri dishes from experimental and control rafts (Fig. 5, ANOVA: $F=2.1, \mathrm{p}>0.05$ ). Larval response to the biofilm at Positions 1 and 2 was not statistically different (ANOVA: $F=0.08, \mathrm{p}=0.77$ ).

Effect of waterborne sponge compounds on macrofouling. During the $4 \mathrm{wk}$, all individuals of Callyspongia (E.) pulvinata remained healthy in their experimental settings. All sponges continued to grow and finally overgrew the mesh. The synthetic sponges had no effect on the fouling communities, organisms settled on these and on the mesh covering them.

On the experimental plates we found 5 green algal species (Chlorophyta: Ulotrichales, Ulva sp., Enteromorpha sp.; Cladophorales, Cladophora sp., Chaetomorpha sp.; Siphonoclades, Dictyosphaera sp.), 2 brown algal species (Phaeophyta: Ectocarpales, Ectocarpus sp., unidentified brown algae), 2 red algal species (Phodophyta: Ceramiales, Ceramium sp.; Corallinales, unidentified encrusting red algae), and 5 invertebrate species (hydrozoan, Cnidaria: Hydrozoa, Obelia sp.; 2 polychaetes, Annelida: Polychaeta, Hydroides elegans and Spirobranchus sp.; bryozoans, Bryozoa: Cheilostomata, Bugula neritina, Schizoporella unicornis).

There were no significant differences (ANOVA: $F=0.5, \mathrm{p}>0.05$ ) between the communities on dishes exposed to fouling on the left and right sides of the frames; therefore, the data were combined for further analysis. All dominant species of macrofoulers were present on both experimental and control frames. At 


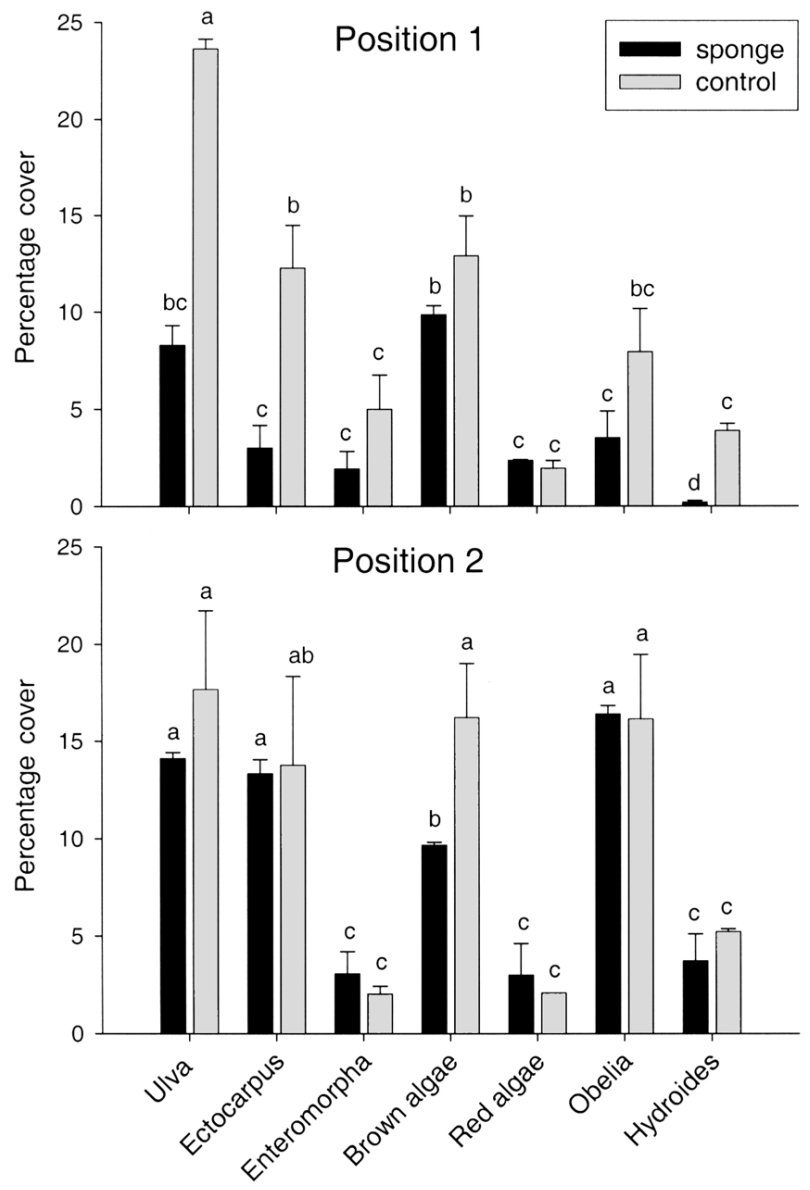

Fig. 6. Percentage cover of dominant macrofouling species on the treatment and control Petri dishes at Positions 1 and 2 of frames after $28 \mathrm{~d}$ from start of the experiment. Dominant algae were Ulva sp., Ectocarpus sp., Enteromorpha sp., unidentified brown algae and unidentified encrusting red algae. Invertebrates included Obelia sp. and Hydroides elegans. Data presentation as in Fig. 2 ( $\mathrm{n}=5$ replicates)

Position 1 (Fig. 1), the alga Ulva sp. had the highest cover in the control dishes (Fig. 6), the polychaete Hydroides elegans the lowest, and the other species moderate. With the exception of the brown algae, all species in the control dishes had a higher cover than those in the experimental dishes (Fig. 6: LSD test, $\mathrm{p}<0.05$ ). At Position 2, there were no differences in percentage cover between control and the experimental dishes. Highest cover was recorded for the algae Ulva sp., Ectocarpus sp., unidentified brown algae and the hydrozoan Obelia loveni (Fig. 6). Other species covered less than $5 \%$ of the area of experimental dishes.

MDS ordination of the percentage of coverage, based on the contribution of the 7 dominant species, showed that community structure differed as a function of treatments of sponge presence and of distance from the sponge (Fig. 7). However, sponge presence appeared to have a stronger effect on percentage of cover than distance from the sponges, as the dishes could be grouped in several clusters based on sponge presence (Fig. 7). All control dishes as well as a few dishes at Position 2 on the experimental frames (lower part of MDS plot) constituted 1 aggregated group, reflecting higher similarities among them. All dishes at Position 1 on the experimental frames and several dishes at Position 2 (upper part of MDS plot) formed a second cluster.

The ANOSIM results demonstrated that among algal and invertebrate recruitment groups, composition was affected both by sponge presence and distance from the sponge (ANOSIM, $\mathrm{p}<0.05$; Table 1). The SIMPER analysis revealed that the macroalgae explained around $59 \%$ of the total Bray-Curtis dissimilarity among the communities in different treatments, while invertebrates accounted for less than $30 \%$. Green alga Ulva sp. contributed 18 to $20 \%$ of the total between-group dissimilarity. Obelia sp. acounted for less than $22 \%$ of dissimilarities between the fouling communities.

Fig. 8A illustrates significant differences in the total percentage of macrofouling coverage among all treatments (ANOVA, $\mathrm{p}<0.000001$ ). The percentage of coverage in the control dishes in Position 2 (Fig. 1) was the highest of all the treatments (ANOVA: LSD test, $p<0.001$ ), while the percentage of coverage in the control dishes at Position 1 was lower, and fouling of experimental dishes at Position 2 was second lowest (ANOVA: LSD test, $\mathrm{p}<0.05$ ). The lowest fouling was found on the experimental dishes exposed close to the sponge (Position 1: Fig. 1). A 2-way ANOVA demon-

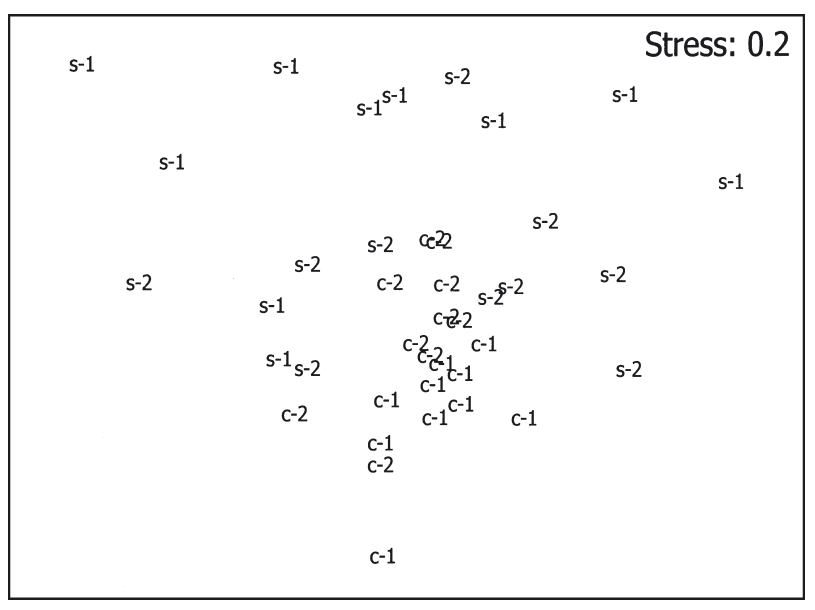

Fig. 7. Multi-dimensional scaling (MDS) ordination of percentage cover of 7 dominant species of macrofoulers (Ulva sp., Ectocarpus sp., Enteromorpha sp., unidentified brown alga, unidentified encrusting red alga, Obelia sp., Hydroides elegans) on treatment (S) and control (C) frames at Positions 1 and 2 in frames $28 \mathrm{~d}$ after start of experiment 
strated that sponge effect (presence or absence of the sponge), position (distance from the sponge), as well as their combined effect determined the total percent coverage in the dishes (Table 2).

The diversity of foulers on the experimental and control plates differed (Fig. 8B). Highest diversity was observed on the control frames, while on the experimental frames diversity was significantly lower (LSD test, $\mathrm{p}<0.05$ ). A 2 -way ANOVA revealed that sponge effect (presence or absence of the sponge) and position determined the diversity of fouling species (Table 2). Analogously, Dunnett's $t$-test revealed differences in

Table 1. Results of ANOSIM (Global R, p) species composition in experimental dishes and SIMPER results for percentage distribution of dominant macrofouling species showing dissimilarity in species composition due to presence or absence of Callyspongia (E.) pulvinata sponge (sponge effect) and distance from sponge (position effect). Percent contributions are averaged over all significant comparisons

\begin{tabular}{|lcc|}
\hline Species & Sponge effect & Position effect \\
& $\mathrm{R}=0.18, \mathrm{p}=0.02$ & $\mathrm{R}=0.23, \mathrm{p}=0.02$ \\
\hline Algae & $\mathbf{5 9 . 4 2} \%$ & $\mathbf{5 6 . 5 4} \%$ \\
Ulva sp. & $20.89 \%$ & $18.19 \%$ \\
Ectocarpus sp. & $18.82 \%$ & $19.51 \%$ \\
Unidentified brown & $12.83 \%$ & $12.05 \%$ \\
algae & $6.88 \%$ & $6.79 \%$ \\
Enteromorpha sp. & $\mathbf{2 5 . 5 0} \%$ & $\mathbf{2 9 . 6 7} \%$ \\
Invertebrates & $17.83 \%$ & $22.04 \%$ \\
Obelia sp. & $7.67 \%$ & $7.63 \%$ \\
Hydroides elegans & $\mathbf{1 5 . 0 8} \%$ & $\mathbf{1 3 . 7 9} \%$ \\
Other species & & \\
\hline
\end{tabular}

Table 2. Results of 2-way ANOVA showing effect of presence or absence of sponge Callyspongia (E.) pulvinata (sponge effect) and distance from sponge (position effect) on total percentage cover (Cover \%), Shannon's diversity (Diversity $H^{\prime}$ ) and Margalef's species richness of macrofouling community developed after $28 \mathrm{~d}$ on Petri dishes

\begin{tabular}{|lrrrr|}
\hline Effect & df & \multicolumn{1}{c}{ MS } & \multicolumn{1}{c|}{$F$} & \multicolumn{1}{c|}{$\mathrm{p}$} \\
\hline Cover \% & & & & \\
$\quad$ Sponge effect & 1 & 2658.566 & 125.321 & $<0.001$ \\
$\quad$ Position effect & 1 & 1328.440 & 62.621 & $<0.001$ \\
Combined effect & 1 & 718.535 & 33.871 & $<0.001$ \\
$\quad$ Residuals & 32 & 21.214 & & \\
Diversity H' & & & & \\
$\quad$ Sponge effect & 1 & 0.048 & 12.969 & 0.010 \\
Position effect & 1 & 0.015 & 4.133 & 0.050 \\
Combined effect & 1 & 0.001 & 0.250 & 0.558 \\
$\quad$ Residuals & 32 & 0.0373 & & \\
Species richness & & & & \\
$\quad$ Sponge effect & 1 & 0.169 & 36.867 & $<0.001$ \\
$\quad$ Position effect & 1 & 0.036 & 8.029 & 0.008 \\
Combined effect & 1 & 0.005 & 1.134 & 0.295 \\
Residuals & 32 & 0.005 & & \\
\hline
\end{tabular}
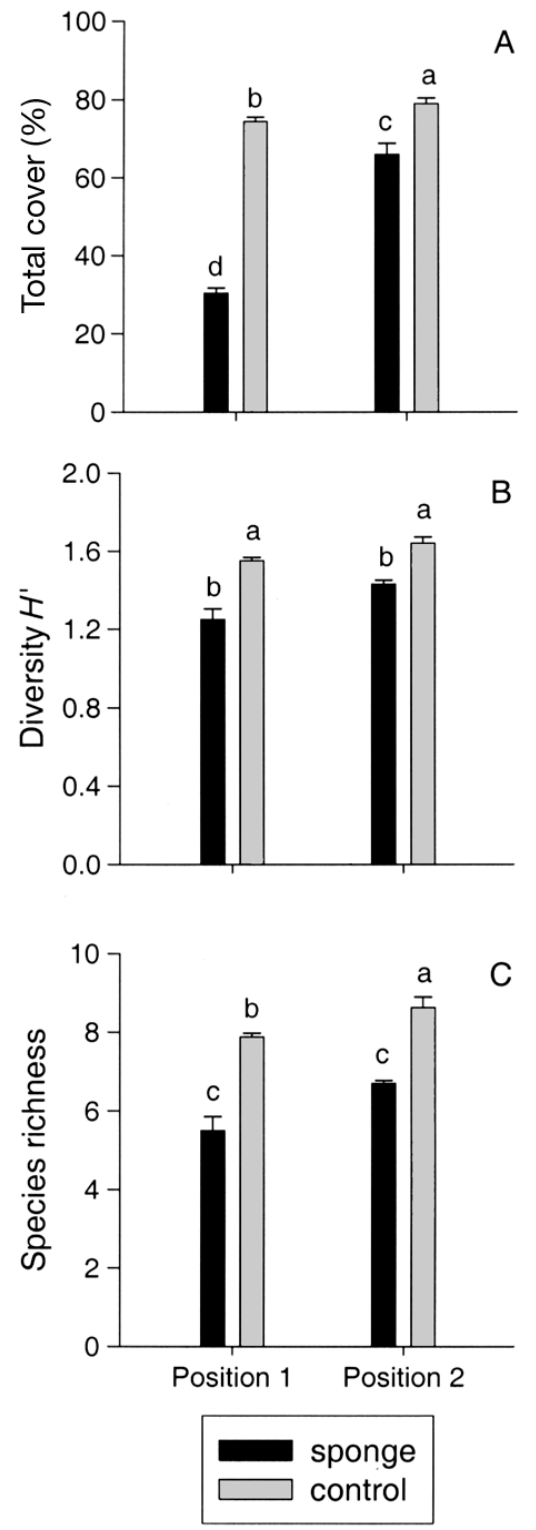

Fig. 8. Callyspongia (E.) pulvinata. Effect of presence or absence on (A) total percentage cover of macrofoulers, (B) diversity, and (C) species richness in treatment (sponge) and control (control) Petri dishes at Positions 1 and 2 of frames $28 \mathrm{~d}$ after from start of experiment. Data are expressed as means \pm SE of 5 replicates. Data presentation as in Fig. $2(n=5$ replicates)

Shannon diversities of communities developed in the experimental and the control dishes (Table 3). There were no differences in the Simpson diversity index except in communities that developed at Position 1 in the experimental dishes and in Position 2 in the control dishes. Diversity of the community (expressed by Hill numbers N1 and N2 and rarefaction) in the experimental dishes was significantly different $(p>0.05)$ from that in the control dishes. 
Table 3. Diversity of macrofouling communities developed on (S) experimental and (C) control dishes exposed to macrofouling on rafts at Positions 1 and 2 for $28 \mathrm{~d}$. ${ }^{a}$ ( (underlined): values significantly different (Dunnett's $t$-test, $\mathrm{p}<0.05$ ) from control C I and C II values, respectively

\begin{tabular}{|c|c|c|c|c|c|c|c|c|c|c|c|c|c|}
\hline \multirow{2}{*}{ Dishes } & \multirow{2}{*}{$\begin{array}{c}\text { Shannon } \\
H^{\prime}(\ln )\end{array}$} & \multicolumn{4}{|c|}{ Simpson } & \multicolumn{7}{|c|}{ _ Hill numbers } & \multirow{2}{*}{$\begin{array}{l}\text { Rarefaction } \\
\quad(50)\end{array}$} \\
\hline & & $\lambda$ & $1-\lambda$ & $\lambda^{\prime}$ & $1-\lambda^{\prime}$ & $\mathrm{N}_{1}$ & $\mathrm{~N}_{2}$ & $\mathrm{~N}_{\infty}$ & $\mathrm{N}_{10}$ & $\mathrm{~N}_{10}{ }^{\prime}$ & $\mathrm{N}_{21}$ & $\mathrm{~N}_{21}^{\prime}$ & \\
\hline C I & $\begin{array}{c}1.64 \\
\pm 0.03\end{array}$ & $\begin{array}{c}0.24 \\
\pm 0.04\end{array}$ & $\begin{array}{c}0.75 \\
\pm 0.03\end{array}$ & $\begin{array}{c}0.23 \\
\pm 0.03\end{array}$ & $\begin{array}{c}0.77 \\
\pm 0.03\end{array}$ & $\begin{array}{c}5.40 \\
\pm 0.36\end{array}$ & $\begin{array}{c}4.54 \\
\pm 0.42\end{array}$ & $\begin{array}{c}3.18 \\
\pm 0.34\end{array}$ & $\begin{array}{c}0.69 \\
\pm 0.05\end{array}$ & $\begin{array}{c}0.64 \\
\pm 0.05\end{array}$ & $\begin{array}{c}0.82 \\
\pm 0.03\end{array}$ & $\begin{array}{c}0.77 \\
\pm 0.04\end{array}$ & $\begin{array}{l}7.41 \\
\pm 0.2\end{array}$ \\
\hline C II & $\begin{array}{c}1.55 \\
\pm 0.02\end{array}$ & $\begin{array}{c}0.25 \\
\pm 0.02\end{array}$ & $\begin{array}{c}0.74 \\
\pm 0.02\end{array}$ & $\begin{array}{c}0.24 \\
\pm 0.02\end{array}$ & $\begin{array}{c}0.79 \\
\pm 0.02\end{array}$ & $\begin{array}{c}4.83 \\
\pm 0.24\end{array}$ & $\begin{array}{c}4.11 \\
\pm 0.25\end{array}$ & $\begin{array}{c}2.86 \\
\pm 0.21\end{array}$ & $\begin{array}{c}0.72 \\
\pm 0.03\end{array}$ & $\begin{array}{c}0.68 \\
\pm 0.03\end{array}$ & $\begin{array}{c}0.84 \\
\pm 0.02\end{array}$ & $\begin{array}{c}0.80 \\
\pm 0.02\end{array}$ & $\begin{array}{c}6.29 \\
\pm 0.26\end{array}$ \\
\hline S I & $\underline{\underline{0.05}}^{\mathrm{ab}}$ & $\begin{array}{c}0.28 \\
\pm 0.02\end{array}$ & $\begin{array}{c}0.71 \\
\pm 0.02\end{array}$ & $\begin{array}{c}0.26 \\
\pm 0.02\end{array}$ & $\underline{0.73}^{0.02}{ }^{\mathrm{b}}$ & $\underline{\underline{0.28}}^{\frac{4.14}{\mathrm{ab}}}$ & $\underline{\underline{0.25}}^{3.67}$ & $\begin{array}{c}2.78 \\
\pm 0.19\end{array}$ & $\begin{array}{c}0.75 \\
\pm 0.02\end{array}$ & $\begin{array}{c}0.69 \\
\pm 0.03\end{array}$ & $\begin{array}{c}0.88 \\
\pm 0.01\end{array}$ & $\begin{array}{c}0.84 \\
\pm 0.02\end{array}$ & $\underline{50.40}^{5.20}$ \\
\hline S II & ${\underline{ \pm 0.02^{\mathrm{ab}}}}^{1.43}$ & $\begin{array}{c}0.24 \\
\pm 0.04\end{array}$ & $\begin{array}{c}0.76 \\
\pm 0.03\end{array}$ & $\begin{array}{c}0.23 \\
\pm 0.03\end{array}$ & $\begin{array}{c}0.77 \\
\pm 0.03\end{array}$ & $\begin{array}{c}5.62 \\
\pm 0.35\end{array}$ & $\underline{4.60}^{ \pm 0.40}$ & $\begin{array}{c}3.22 \\
\pm 0.32\end{array}$ & $\begin{array}{c}0.66 \\
\pm 0.04\end{array}$ & $\begin{array}{c}0.62 \\
\pm 0.05\end{array}$ & $\begin{array}{c}0.81 \\
\pm 0.03\end{array}$ & $\begin{array}{c}0.75 \\
\pm 0.04\end{array}$ & $\underbrace{\mathrm{b}}_{ \pm \frac{7.97}{0.16}}$ \\
\hline
\end{tabular}

Highest species richness was found on the control plates at Position 2 (Fig. 8C). Species richness on the control plates at Position 1 was moderate. A 2-way ANOVA demonstrated that sponge effect and position of the Petri dishes determined species richness in the experimental dishes (Table 2), which was lower than the controls at both positions.

\section{DISCUSSION}

Marine sponges contain a large number of compounds that show antibacterial (Walker et al. 1985, Austin 2001) and antilarval (Becerro et al. 1997, Lee \& Qian 2003) activity in laboratory bioassays. The present study combined laboratory and field experiments to assess the effects of waterborne compounds from the sponge Callyspongia (E.) pulvinata on marine microand macrofouling organisms. Evidence from the laboratory demonstrated that CSW from this sponge suppressed the growth of the pennate diatom Nitzschia paleacea and the larval settlement of the tubeworm $\mathrm{Hy}$ droides elegans, but did not inhibit the growth of 9 bacterial strains isolated from natural biofilms. At tissuelevel concentration, the waterborne metabolites were toxic, with $80 \%$ of $H$. elegans larvae dying in undiluted CSW within $24 \mathrm{~h}$. Similarly, the density of living diatoms exposed to CSW was 5 times less than that in control dishes. After being diluted 5 times, CSW still inhibited the larval settlement of $H$. elegans and the growth of diatoms but with low toxicity. However, when diluted 10 times, CSW had no effect on either larval or microbial settlement.

The toxicity of sponges has been well documented (Becerro et al. 1997, Lee \& Qian 2003). For instance, the spherous cells of the encrusting sponge Crambe crambe produce toxic guanidine alkaloids that seem to have multiple functions in nature, such as antifouling, an- tipredation, and allelopathic functions in space competition (Becerro et al. 1997). Substances exuded by the intertidal sponge Aplysina fistularis are toxic to gastropod veliger larvae of nudibranchs, and caused abnormal behavior in all adult invertebrates tested by Thompson (1985). The sponge Mycale adhaerens inhibits larval settlement of Hydroides elegans by excreting toxic waterborne compounds (Lee \& Qian 2003).

When Davis et al. (1989) reviewed the data on natural antifoulants, little was known about their individual producers, the location of production and storage in the basibiont, nor about the release rates and the effective concentrations at ecologically relevant interfaces. Over the last decade, some progress has been made. The metabolites at or near the surface of the producing organism(s) have been extracted, quantified, and tested at 'realistic' concentrations on potential and therefore ecologically meaningful epibiota in the laboratory or in the field (Maximilien et al. 1998).

Thompson et al. $(1984,1985)$ carried out some finescale investigations of sponge-derived bioactive substances described and localised as the brominated bioactive metabolites aerothionin and homoaerothionin in spherulous cells of the sponge Aplysina fistularis. Walker et al. (1985) further quantified the in situ release rates of these metabolites. The release rates measured in their study may have been over a high range of natural concentrations, since they were measured immediately following reimmersion of the sponge. Although the exudates had no effect in antifouling bioassays (Thompson et al. 1985), they did inhibit the feeding response of potential fouling organisms, and may therefore have significantly sublethal effects on epibiotic postcolonisation. In general, large, brightly coloured, shallow-water sponges have better defences against fouling and predators than small, darkly coloured deep-water sponges (Maurer et al. 2003). However, this generalisation may not hold for all sponge species. For instance, many small 
species, such as Haliclona spp., Crambe spp., Mycale spp., etc. may very well be defended by the production of toxic substances (Becerro et al. 1994, 1997, Lee \& Qian 2003).

There is a general assumption that substances inducing larval settlement in marine invertebrates differ in some aspects from deterrents (Steinberg et al. 2001, 2002). The few ecologically relevant settlement-deterrents known are non-polar surface-associated metabolites. Steinberg et al. (2001) suggested that, in contrast to deterrents, settlement inducers (such as peptides and carbohydrates) are commonly waterborne. This is in contrast to previous assumptions (e.g. Pawlik 1992) that inducers are surface-bound. There are exceptions to the rule 'inducers are soluble' (e.g. for larvae of barnacles, cf. Clare \& Matsumura 2000): some of the surface-bound inducing cues, such as those of agariciid corals (Morse \& Morse 1991) when degraded or hydrolysed, often reveal active waterborne subunits, suggesting that small soluble compounds are connected with surface-associated exceptions (Steinberg et al. 2001). In contrast, when producing deterrents, an optimal strategy for hosts is to maximise the concentration of metabolites at or close to their surface (Jennings \& Steinberg 1997). Producing or delivering nonpolar metabolites at those interfaces that are exposed to the environment may achieve this best.

Evidence from research on seaweeds (de Nys \& Steinberg 1999) and marine sponges (e.g. Marin et al. 1998) suggests that natural antifoulants will primarily be nonpolar bioactive metabolites localised within an organism in such a way that the metabolites can be released from interfaces in contact with the environment. Hydrophobic metabolites such as the furanosesquiterpenoids from the sponge Dysidea fragilis (Marin et al. 1998) can remain adsorbed to or associated with the organic surfaces of the producing organisms, providing a more persistent concentration of deterrent metabolites at the surface. These must not necessarily be outer surfaces. Most suspension-feeding invertebrates produce a water current through the interior of their body cavities, for the uptake of oxygen, dissolved organic matter (DOM) or particulate organic matter (POM), and the expulsion of gametes or waste products via internal epithelia (among other exchanges with the external environment). This holds particularly for sponges, in which internal (entodermal) epithelia (endopinacoderm) serve as exchange interfaces with the external environment. In contrast to non-polar metabolites, polar metabolites such as phlorotannins (Lau \& Qian 1997, Jennings \& Steinberg 1997) are assumed to be less effective because of their hydrophilic tendency, with subsequent rapid dissolution away from the surface of the affected organism. Examples for the production of polar metabolites are provided by marine sponges. Because of their complex system of aquiferous channels and cavities, sponges may be able to concentrate polar metabolites intra- or intercellulary or within internal cavities, resulting in high concentrations of metabolites near their internal or external surfaces. Sepčić et al. (1997) isolated the polymer 3-alkylpyridinium from the marine sponge Reniera sarai that is soluble only in water, forming water-dissolved supramolecular structures.

Inhibitory effects of sponge extracts in laboratory assays do not necessarily imply similar effects under natural conditions. Our field experiments investigated the effect of waterborne compounds from the sponge Callyspongia (E.) pulvinata on the development of the microfouling and macrofouling communities on artificial substrates over distances of 13 and $50 \mathrm{~cm}$. The planktonic pool of potential colonisers seemed to be homogeneously distributed in the experimental area. All microfouling and macrofouling species settled onto both experimental and control dishes.

No difference in bacterial density was found between experimental and control dishes. This suggests that waterborne compounds from the sponge Halichondria panicea had no antibacterial effect, which was supported by the results of the laboratory experiments. Nevertheless, the composition of bacterial species in experimental and control dishes may be different. We shall investigate this in future experiments. Diatom recruitment in the presence of the sponge was 4 times less intensive than in control dishes. Similar results were obtained in our laboratory experiments with the benthic diatom Nitzschia paleacea. The antifouling effect of waterborne compounds from the gorgonians Pseudopterogorgia americana and P. acerosa on diatom fouling has been demonstrated previously in field experiments (Targett 1988). However, the present study is the first account of allelopathic effects of sponges under field conditions.

The densities of bacteria and diatoms in the control dishes differed between Positions 1 and 2 (Fig. 4). Bacteria dominated at Position 1, while diatoms were more abundant at Position 2. We assumed that the increased water depth at Position 2 resulted in an increase in diatom density and a decrease in bacterial density. This was reflected in the dominance of small diatoms (10 to $15 \mu \mathrm{m}$ ), particularly Diploneis sp. at Position 2, while in the upper dishes (Position 1), large (120 to $300 \mu \mathrm{m}$ ) species of Nitzschia sp. and Synedra sp. were more abundant.

Previously, it has been demonstrated that the number and the composition of bacteria and diatoms on artificial substrates are related to the depth of exposure (Moeseneder et al. 2001, Bily 2002). Distinctive differences were found in these studies between deep waters and surface waters. The small-scale variation 
(within a range of $50 \mathrm{~cm}$ ) of diatoms and bacterial densities found in our investigation, however, has not been recorded earlier.

Several studies have shown that orientation, depth, and position of artificial substrata affect macrofouling communities (Relini et al. 1998, Dobretsov \& Miron 2001, Glasby \& Connel 2001). The results of those studies demonstrated that maximal fouling communities developed in surface waters, whereas at depths greater than $10 \mathrm{~m}$, biomass and species densities decreased. On artificial substrates exposed to fouling in the South China Sea, hydroids, barnacles and oysters represented dominant macrofoulers in surface waters (Yan et al. 1999). In this study, a substantial reduction in biomass and species diversity of fouling communities occurred with increasing depth.

In our experiments, the alga Ulva sp., Ectocarpus sp. and unidentified brown algae, as well as invertebrate Obelia sp. were the dominant organisms in both the experimental and control dishes. Previously, the invertebrates Balanus reticulatus, B. trigonus, Styela plicata, Mycale adhaerens, Bugula neritina, Saccostrea echinata and Perna viridis, as well as the alga U. lactuca were often reported to dominate the biofouling community on artificial substrates in Hong Kong waters (Huang \& Mak 1982, Huang et al. 1999, Qiu et al. 2003). The short duration of our experiments and the dominance of algae may explain the differences between our results and the findings of other authors.

In the present field experiments, the recruitment rate differed between the control and experimental dishes. The highest total percentage cover of fouling species was in the control dishes, the lowest in the experimental dishes at Position 1 (close to the sponge). This suggests that waterborne metabolites of the sponge Callyspongia (E.) pulvinata could modify biofouling in the near vicinity $(13 \mathrm{~cm})$. Algae (Ulva sp., Ectocarpus sp., Enteromorpha sp., unidentified brown algae) and invertebrates (Obelia sp., Hydroides elegans) were most sensitive to the presence of sponges. Algae contributed about $59 \%$ to the total Bray-Curtis dissimilarity in species composition between the experimental and the control dishes, while invertebrates contributed only about $17 \%$. This may be explained by the dominance of the algal species in the macrofouling organisms during our experiments. Other species of algae and invertebrates were present at much lower densities, and were patchily distributed or present at the same densities as in the control dishes. The composition of macrofouling communities on experimental (exposed near the sponge) and control dishes differed. The diversity and species richness of the macrofouling communities developed in the control dishes was significantly higher than those in the experimental dishes. Our results indicate that waterborne sponge metabolites affected the recruitment of foulers onto the experimental plates in terms of both abundances and species composition of the resulting macrofouling communities.

In our field experiments total species coverage, diversity and species richness differed between dishes as a function of distance from the sponge. With increasing distance from the sponge, percentage total cover, diversity and species richness of macrofoulers increased in the experimental dishes. This could be due to (1) the sponge metabolites becoming diluted with increasing distance from the sponge, resulting in a concentration not high enough to suppress macrofouling; (2) the greater depth at Position 2 might cause changes in the macrofouling community (this is supported by the different macrofouling communities in the control dishes at Positions 1 and 2 in our experiments); (3) the combined effect of the dilution of antifouling compounds and depth on fouling communities.

In previous experiments, we showed the effects of chemical compounds from macroalgae on larval recruitment in the field (Dobretsov 1999, Dobretsov \& Wahl 2001). The results of these investigations suggested that recruitment preferences of Mytilus edulis larvae for artificial substrata were dependent on the organismic neighbourhood. Waterborne secondary metabolites of Cladophora rupestris attracted mussel larvae, while those of Chorda tomentosa were neutral and those of Laminaria saccharina were repellent (Dobretsov 1999). Microhabitat selection by cyanobacteria, diatoms, sessile ciliates, and red algae was also studied in field experiments in Kiel Bay (Wahl \& Mark 1999). It was demonstrated that epibiotic invaders preferred artificial substrata to living surfaces of basibionts. In addition, thalli of Laminaria sp. and Fucus sp. were more repellent to micro- and macrofouling than surfaces of Delesseria sp. and Zostera sp.

There has been only 1 field experiment in which the effect of 6 different species of sponges (Chondrilla sp., Halichondria sp., Haliclona sp., Tedania sp., Lissodendoryx sp. and Terpios sp.) on larval recruitment was investigated at several locations (Bingham \& Young 1991). The investigators demonstrated that the settlement of 1 species was suppressed, while the recruitment of 4 other species was enhanced on ceramic settlement panels exposed close to sponges in the field. The recruitment of 21 other invertebrate species did not correlate with the presence of sponges. The results suggested that allelopathic effects of sponges were less important than local hydrodynamics and a heterogeneous larval supply in determining the recruitment patterns on surfaces adjacent to sponges. Because Bingham \& Young (1991) did not provide any laboratory evidence of antibacterial or antilarval activity of waterborne compounds of these sponges, and did not investigate the density of microfoulers on experimental 
plates, the results of their field experiments need to be interpreted with caution.

There is an increasing body of evidence that biofilms play an important role in the settlement of invertebrate larvae and algal spores (reviewed by Wieczorek \& Todd 1998). In our experiments, we tested the hypothesis that waterborne compounds of sponges indirectly affect the settlement of larvae, i.e. by changing the composition of microfouling communities on experimental plates. Our laboratory experiments with $\mathrm{Hy}$ droides elegans demonstrated that the larval settlement patterns were similar in the experimental and the control dishes. This suggests that while there were differences in densities and, possibly, in the species composition of diatoms and bacteria in the experimental and control dishes, larval response to biofilms was similar. Hence, differences in macrofouling communities may be interpreted as a result of direct inhibition of larval and algal spore settlement by waterborne compounds of the sponge Callyspongia (E.) pulvinata.

In the study of chemical defence mechanisms, marine sponges (Porifera) have long been a focal point of natural-product chemists because of their unique range of bioactive compounds, some of which are thought to function in deterring predators, competitors and epibiotic settlers (Bakus et al. 1986). At the same time, there is but little evidence of the functionality of these compounds in the natural environment against naturally occurring micro- and macrofoulers. In our laboratory and field experiments, we showed that waterborne metabolites from the sponge Callyspongia (E.) pulvinata a have a potential to reduce or inhibit recruitment of micro- and macrofoulers on their surface or even in their immediate neighbourhood. The structure of the macrofouling community was also affected. The antifouling effect of the sponge was based on the secretion of waterborne metabolites, which inhibited the growth of diatoms and were toxic to the larvae. Therefore, different fouling communities may be established, depending on the proximity or absence of a specific sponge species.

Acknowledgements. This investigation was supported by RGC grants (CA00/01.Sc01, HKUST6119/01M, HKUST6100/ 02M, HKUST6281/03M) to P.-Y.Q.

\section{LITERATURE CITED}

Acar JF (1980) The disc susceptibility test. In: Lorian V (ed) Antibiotics in laboratory and medicine. Williams \& Wilkins, Baltimore, p 24-54

Armstrong E, Yan L, Boyd KG, Wright PC, Burgess JG (2001) The symbiotic role of marine microbes on living surfaces. Hydrobiologia 461:37-40

Austin B (2001) Novel pharmaceutical compounds from marine bacteria. In: Fingerman M, Nagabhushanam R (eds) Recent advances in marine biotechnology, Vol 6. Bioorganic compounds: chemistry and biomedical applications. Science Publishers, Plymouth, p 1-19

Bakus GJ, Targett NM, Schulte B (1986) Chemical ecology of marine organisms: an overview. J Chem Ecol 12:951-987

Becerro MA, Lopez NI, Turon X, Uriz MJ (1994) Antimicrobial activity and surface bacterial film in marine sponges. J Exp Mar Biol Ecol 179:195-205

Becerro MA, Uriz MJ, Twan X (1997) Chemically-mediated interactions in benthic organisms - the chemical ecology of Crambe crambe (Porifera Becilosclerida). Hydrobiologia 355:77-89

Bergquist PR (1978) Sponges. University of California Press, Berkeley

Bily M (2002) Periphyton algal communities from the flooded quarry Skali-species composition, vertical distribution and seasonal changes. Algol Stud 142:145-168

Bingham BL, Young CM (1991) Influence of sponge on invertebrate recruitment: a field test of allelopathy. Mar Biol 109:19-26

Blunt JW, Copp BR, Munro MHG, Northcote PT, Prinsep MR (2003) Marine natural products. Nat Prod Rep 20:1-131

Bryan JP, Kreider L, Qian PY (1997) Settlement of the polychaete Hydroides elegans on surfaces of the cheilostome bryozoan Bugula neritina: evidence for a chemically mediated relationship. J Exp Mar Biol Ecol 220:171-190

Burja AM, Hill RT (2001) Microbial symbionts of the Australian Great Barrier Reef sponge, Candidaspongia flabellata. Hydrobiologia 461:41-47

Clare AS, Matsumura K (2000) Nature and perception of barnacle settlement pheromones. Biofouling 15:57-71

Clarke KR, Gorley RN (2001) Primer v5: user manual/tutorial. Primer-E, Plymouth

Davis A (1998) Antifouling defence in a subtidal guild of temperate zone encrusting invertebrates. Biofouling 12: 305-320

Davis AR, Targett NM, McConell OJ, Young CM (1989) Epibiosis of marine algae and benthic invertebrates: natural products chemistry and other mechanisms inhibiting settlement and growth. In: Scheuer PJ (ed) Bioorganic marine chemistry. Springer-Verlag, Berlin, p 85-96

de Nys R, Steinberg PD (1999) Role of secondary metabolites from algae and seagrasses in biofouling control. In: Fingerman M, Nagabhushanam R, Thompson MF (eds) Recent advances in marine biotechnology, Vol III. Biofilms, bioadhesion, corrosion, and biofouling. Oxford Press, Oxford, p 223-244

Dobretsov SV (1999) Effects of macroalgae and biofilm on settlement of blue mussel (Mytilus edulis L.) larvae. Biofouling 14:153-165

Dobretsov SV, Miron G (2001) Larval and post-larval vertical distribution of the mussel Mytilus edulis L. in the White Sea. Mar Ecol Prog Ser 218:179-187

Dobretsov S, Qian PY (2002) Effect of bacteria associated with the green alga Ulva reticulata on marine micro- and macrofouling. Biofouling 18:217-228

Dobretsov S, Wahl M (2001) Recruitment preferences of blue mussel spat (Mytilus edulis) for different substrata and microhabitats in the White Sea (Russia). Hydrobiologia 445:27-35

Friedrich AB, Fischer I, Proksch P, Hacker J, Hentschel U (2001) Temporal variation of the microbial community associated with the Mediterranean sponge Aplysina aerophoba. FEMS Microbiol Ecol 38:105-113

Glasby TM, Connel SD (2001) Orientation and position of substrata have large effects on epibiotic assemblages. Mar Ecol Prog Ser 214:127-135 
Harder T, Lau SCK, Dahms HU, Qian PY (2002) Isolation of bacterial metabolites as natural inducers for larval settlement in the marine polychaete Hydroides elegans (Haswell). J Chem Ecol 28:2009-2023

Hentschel U, Schmid M, Wagner M, Fieseler L, Gernert C, Hacker J (2001) Isolation and phylogenetic analysis of bacteria with antimicrobial activities from Mediterranean sponges Aplysina aerophoba and Aplysina cavernicola. FEMS Microbiol Ecol 35:305-312

Hentschel U, Hopke J, Horn M, Friedrich A, Wagner M, Hacker J, Moore B (2002) Molecular evidence for a uniform microbial community in sponges from different oceans. Appl Environ Microbiol 68:4431-4440

Hoeller U, Wright AD, Matthee GF, Konig GM, Draeger S, Aust HJ, Shulz B (2000) Fungi from marine sponges: diversity, biological activity and secondary metabolites. Mycol Res 104:1354-1365

Holmström C, Rittschof D, Kjelleberg S (1992) Inhibition of settlement by larvae of Balanus amphitrite and Cliona intestinalis by surface-colonising marine bacterium. Appl Environ Microbiol 58:2111-2115

Huang ZG, Mak PMS (1982) Studies on biofouling in Tolo Harbour. In: Morton B, Tseng CK (eds) Proc First International Marine Biological Workshop: The Marine Flora and Fauna of Hong Kong and Southern China, Hong Kong 1980. Hong Kong University Press, Hong Kong, p 767-787

Huang Z, Li Z, Morton B, Leung TY (1999) Biofouling of cage macroculture zones in the southern waters of Hong Kong. Asian Mar Biol 16:77-99

James G, Holmström C, Kjelleberg S (1996) Purification and characterization of a novel antibacterial protein from the marine bacterium D2. Appl Environ Microbiol 62: $2783-2788$

Jennings JG, Steinberg PD (1997) Phlorotannins versus other factors affecting epiphyte abundance on the kelp Ecklonia radiata. Oecologia 109:461-473

Jin DX, Chen ZD, Li JM, Junmin L, Li SC (1985) The marine benthic diatoms in China, Vol 1. China Ocean Press, Beijing

Kelman D, Kashman Y, Rosenberg E, Ilan M, Ifrach I, Loya Y (2001) Antimicrobial activity of the reef sponge Amphimedon viridis from the Red Sea: evidence for selective toxicity. Aquat Microb Ecol 24:9-16

Kirchman D, Graham S, Reish D, Mitchell R (1982) Bacteria induce settlement and metamorphosis of Janua (Dexiospira) brasiliensis Grube (Polychaeta: Spirorbidae). J Exp Mar Biol Ecol 56:153-163

Kobayashi M, Kitagawa I (1998) Likely microbial participation in the production of bioactive marine sponge chemical constituents. In: Watanabe Y, Fusetani N (eds) Sponge sciences-multidisciplinary perspectives. SpringerVerlag, Berlin, p 377-389

Lau SCK, Qian PY (1997) Phlorotannins and related compounds as larval settlement inhibitors of the tube-building polychaete Hydroides elegans. Mar Ecol Prog Ser 159: 217-227

Lau SCK, Mak KKW, Chen F, Qian PY (2002) Bioactivity of bacterial strains from marine biofilms in Hong Kong waters for the induction of larval settlement in the marine polychaete Hydroides elegans. Mar Ecol Prog Ser 226: 301-310

Lau SCK, Thiyagarajan V, Qian PY (2003) The bioactivity of bacterial isolates in Hong Kong waters for the inhibition of barnacle (Balanus amphitrite Darwin) settlement. J Exp Mar Biol Ecol 282:43-60

Lee OO, Qian PY (2003) Chemical control of bacterial epibiosis and larval settlement of Hydroides elegans in the red sponge Mycale adherens. Biofouling 19:171-180

Maki JS, Rittschof D, Costlow JD, Mitchell R (1988) Inhibition of attachment of larval barnacles, Balanus amphitrite, by bacterial surface films. Mar Biol 97:199-206

Margot H, Acebal C, Toril E, Amils R, Fernandez Puentes JL (2002) Consistent association of crenarchaeal Archaea with sponges of the genus Axinella. Mar Biol 140:739-745

Marin A, Lopez MD, Esteban MA, Meseguer J, Munoz J, Fontana A (1998) Anatomical and ultrastructural studies of chemical defence in the sponge Dysidea fragilis. Mar Biol 131:639-645

Maurer ER, Gomez R, Braekman JC, Van de Vyver G, Van Soest RWM, Devijver C (2003) Primary cultures from the marine sponge Xestospongia muta (Petrosiidae, Haplosclerida). J Biotechnol 100:169-176

Maximilien R, de Nys R, Holmström C, Gram L, Givskov M, Crass K, Kjelleberg S, Steinberg PD (1998) Chemical mediation of bacterial surface colonisation by secondary metabolites from the red alga Delisea pulchra. Aquat Microb Ecol 15:233-246

Moeseneder MM, Winter C, Herndl GJ (2001) Horizontal and vertical complexity of attached and free-living bacteria of the eastern Mediterranean Sea, determined by 16S rDNA and 16S rRNA fingerprints. Limnol Oceanogr 46:95-107

Morse DE, Morse ANC (1991) Enzymatic characterization of the morphogen recognized by Agaricia humilis (scleractinian coral) larvae. Biol Bull (Woods Hole) 181:104-112

Newbold RW, Jensen PR, Fenical W, Pawlik JR (1999) Antimicrobial activity of Caribbean sponge extracts. Aquat Microb Ecol 19:279-284

Pawlik JR (1992) Chemical ecology of the settlement of benthic marine invertebrates. Oceanogr Mar Biol Annu Rev 30:273-291

Pechenik JA, Qian PY (1998) Onset and maintenance of metamorphic competence in the marine polychaete Hydroides elegans Haswell in reponse to three chemical cues. J Exp Mar Biol Ecol 226:51-74

Qiu JW, Thiyagarajan V, Leung AWY, Qian PY (2003) Development of a marine subtidal epibiotic community in Hong Kong: implications for deployment of artificial reefs. Biofouling 19:37-46

Relini G, Tixi F, Relini M, Torchia G (1998) The macrofouling on offshore platforms at Ravenna. Int Biodeterior Biodegrad 41:41-55

Ruetzler K (1985) Associations between Caribbean sponges and photosynthetic organisms. In: Ruetzler K (ed) New perspectives in sponge biology. Smithsonian Institution Press, Washington, DC, p 455-466

Sepčić K, Guella G, Mancini I, Pietra F and 5 others (1997) Characterisation of anticholinesterase 3 alkylpyridinium polymers from the marine sponge Reniera sarai in aqueous solutions. J Nat Prod (Lloydia) 60:991-996

Sera Y, Adachi K, Nishida F, Shizuri Y (1999) A new sesquiterpene as an antifouling substance from a Palauan marine sponge, Dysidea herbacea. J Nat Prod (Lloydia) 62: 395-396

Shapiro SS, Wilk MB (1965) An analysis of variance test for normality (complete samples). Biometrika 52:591-611

Steinberg P, de Nys R, Kjelleberg S (2001) Chemical mediation of surface colonisation. In: McClintock JB, Baker BJ (eds) Marine chemical ecology. CRC Press, Boca Raton, FL, p 355-387

Steinberg PD, de Nys R, Kjelleberg S (2002) Chemical cues for surface colonisation. J Chem Ecol 28:1935-1951

Targett NM (1988) Allochemistry in marine organisms: chemical fouling and antifouling strategies. In: Thompson MF Sarojini R, Nagabhushanam R (eds) Marine biodeteriora- 
tion: advanced techniques applicable to the Indian Ocean. Marine Science Institute, University of Delaware, Lewes, p 609-617

Thacker RW, Starnes S (2003) Host specificity of the symbiotic cyanobacterium Oscillatoria spongeliae in marine sponges, Dysidea spp. Mar Biol 142:643-648

Thakur NL, Anil AC (2000) Antibacterial activity of the sponge Ircinia ramosa: importance of its surface-associated bacteria. J Chem Ecol 26:57-72

Thompson JE (1985) Exudation of biologically-active metabolites in the sponge Aplysina fistularis. 1. Biological evidence. Mar Biol 88:23-26

Thompson JE, Barrow KD, Faulkner DJ (1984) Localisation of two brominated metabolites, aerothionin and homoaerothionin, in spherulous cells of the marine sponge Aplysina fistularis. Acta Zool (Stockh) 64:199-220

Thompson JE, Walker RP, Faulkner DJ (1985) Screening and bioassays for biologically-active substances from forty marine sponge species from San Diego, California, USA. Mar Biol 88:11-21

Thoms C, Horn M, Wagner M, Hentschel U, Proksch P (2003) Monitoring microbial diversity and natural product profiles of the sponge Aplysina cavernicola following transplantation. Mar Biol 142:685-692

Tomono Y, Hirota H, Fusetani N (1998) Antifouling compounds against barnacle (Balanus amphitrite) larvae from the marine sponge Acanthella cavernosa. In: Watanabe Y, Fusetani N (eds) Sponge sciences - multidisciplinary perspectives. Springer-Verlag, Berlin, p 413-424

Tsukamoto S, Kato H, Hirota H, Fusetani N (1997) Antifouling

Editorial responsibility: Otto Kinne (Editor),

Oldendorf/Luhe, Germany terpenes and steroids against barnacle larvae from marine sponges. Biofouling 11:283-291

Unson MD, Holland ND, Faulkner DJ (1994) A brominated secondary metabolite synthesized by the cyanobacterial symbiont of a marine sponge and accumulation of the crystalline metabolite in the sponge tissue. Mar Biol 119:1-11

Wahl M (1997) Living attached: aufwuchs, fouling, epibiosis. In: Nagabhushanam R, Thompson M (eds) Fouling organisms of the Indian Ocean: biology and control technology. Oxford \& IBH, Calcutta, p 31-84

Wahl M (2001) Small scale variability of benthic assemblages: biogenic neighborhood effects. J Exp Mar Biol Ecol 258: 101-114

Wahl M, Mark O (1999) The predominantly facultative nature of epibiosis: experimental and observational experience. Mar Ecol Prog Ser 187:59-66

Walker RP, Thompson JE, Faulkner DJ (1985) Exudation of biologically-active metabolites in the sponge Aplysina fistularis. II. Chemical evidence. Mar Biol 88:27-32

Warwick RM, Clarke KR (1995) New 'biodiversity' measures reveal a decrease in taxonomic distinctness with increasing stress. Mar Ecol Prog Ser 129:301-305

Wieczorek C, Todd CD (1998) Inhibition and facilitation of settlement of epifaunal marine invertebrate larvae by microbial biofilm cues. Biofouling 12:81-118

Yan T, Yan WX, Yu D, Wang HJ, Yin Y, Li GH (1999) Marine fouling in offshore areas east of Hainan Island, northern China Sea. Chin J Oceanol Limnol 17:233-239

Zar JH (1996) Biostatistical analysis, 3rd edn. Prentice-Hall, Upper Saddle River, NJ

Submitted: July 14, 2003; Accepted: October 25, 2003

Proofs received from author(s): April 14, 2004 